\title{
INTERNET KAO GLAVNI AGENS TRANSFORMACIJE ŽANROVSKIH SADRŽAJA MEDIJA
}

\section{Maja Kostadinović ${ }^{1}$}

${ }^{1}$ Filozofski fakultet, Univerzitet u Nišu, Niš, Srbija

\section{Correspondence:}

Maja Kostadinović

e-mail:

mayavuyinovic@gmail.com

\section{Rezime:}

Savremeni svet obogaćen je novim tehnologijama koje neverovatnom brzinom menjaju uobičajene sadržaje masovnih medija. Informacije koje su nekada danima, pa i mesecima, putovale s kraja na kraj sveta, danas, takoreći, brzinom svetlosti dospevaju do njih. Takve promene uslovile su i promenu žanrovskih struktura medija u kojima danas dominiraju vesti i informacije, a u drugi plan potisnuti su analitički tekstovi, komentari, kritike, pa čak i reportaže. Istovremeno imamo i pojavu nekih novih formi, poput sve popularnijih blogova.

Ovaj rad pokušava da pronađe odgovor na pitanje u kojoj meri je menjajući žanrovske forme vreme uticalo na verodostojnost medijskih sadržaja kojima smo svakodnevno izloženi. Takođe, ukazuje na potrebu medijskog opismenjavanja svih neposrednih aktera medija, vlasnika, urednika, novinara, korisnika medija.

Ključne reči:

mediji, žanrovi, medijska pismenost, internet, blog.

\section{UVOD}

Pod uticajem interneta, digitalizacije i društvenih mreža, savremeno novinarstvo transformiše se brže nego što se to $u$ istoriji ikada dešavalo. Promene su najpre zahvatile Sjedinjene Američke Države i zapadnu Evro$\mathrm{pu}$, ali su se uprkos brojnim specifičnostima medijskih sistema veoma brzo proširile i na istočni deo Evrope, pa i na Srbiju. Značajnu ulogu u promenama odigrala je i ekonomska kriza koja je 2008. godine zahvatila čitav svet, zbog čega su značajno opali tiraži svih dnevnih i nedeljnih listova u svetu, pa i kod nas.

Posledica toga je da tradicionalni mediji gube trku sa vremenom, a menjaju se i uobičajene navike ljudi širom sveta. Prelistavanje dnevne štampe uz jutarnju kaficu odlazi u prošlost. Mladi ljudi, ali i oni koji su već u godinama, sate i sate provode uz svoje računare „prelistavajući” internet izdanja tradicionalnih medija koja im omogućuju da se aktivno uključe u diskusije o problemima i događajima koji se odigravaju pored njih, ali i hiljadama kilometara dalje. Sve je više onih koji učestvuju u različitim forumima na društvenim mrežama, sve je više blogova i blogera, sve je više novih novinara. Profesija se, zahvaljujući tehnološkim rešenjima koja su sve modernija i brža, demokratizuje, ali i značajno menja. 
Na udaru je u prvom redu kredibilitet novinarstva i novinara. Odavno je poznato da je jedna od najvećih nevolja novinarstva vezana za rokove objavljivanja, odnosno štampanja tekstova, ali je pojava interneta dovela i do toga da su te teškoće pojačane. Novinari sada moraju da vode računa ne samo o tome kako da tekst ubace u novinu do početka njenog štampanja, veći kako da preteknu kolege koje imaju brza i moderna internet izdanja. Zbog toga, kao i zbog besomučne trke za profitom, koja često znači i opstanak medija, strada pouzdanost informacija koje se objavljuju. Nekadašnje iscrpne, interpretativne tekstove sa najmanje dva ili tri sagovornika, sa mnoštvom podataka i korisnim i zanimljivim antrfileima, zamenjuju tekstovi sa samo jednim sagovornikom (često anonimnim), dva podatka i velikom fotografijom.

Upravo zbog toga, u ovom radu bavimo se uticajem interneta na žanrovsku strukturu medija. Polazeći od premise da je budućnost već počela i da su se mnoge promene već dogodile, istražujemo kakva je budućnost žanrovskih sadržaja medija. Polazimo od tvrdnje da je sa ekspanzijom interneta došlo do preoblikovanja novinarskih žanrova. Suština trke za informacijama jeste, pre svega, skraćivanje vremena potrebnog da stignu do krajnjih korisnika. Zbog toga je tiplogija žanrova promenjena u korist faktografskih žanrova, dakle pre svega kratkih vesti, vesti i izveštaja. U takvoj situaciji pojedini žanrovi nestaju iz medija, dok su na sceni novi hibridni žanrovi, čija primena omogućuje bolju komunikaciju sa čitaocima internetskih stranica. Istovremeno, uočava se pad kvantiteta informativnih priloga, a mesto se pre svega ustupa lakim zabavnim i senzacionalističkim sadržajima. Ovakav trend posebno je prisutan na televizijama, a ono što brine jeste činjenica da takve programe emituju televizije sa nacionalnim frekvencijama.

Naš cilj je da utvrdimo koji su danas najkorišćeniji žanrovi u tradicionalnim i internet medijima, odnosno da li su neki od tipičnih žanrovskih oblika (članak, reportaža i sl.) ustupili svoje mesto drugim, kraćim i osnovnim faktografskim žanrovima i kakve se kombinovane forme mogu pronaći u novim medijima. Takođe, pokušaćemo da pokažemo kakav je ne samo profesionalni, već i društveni aspekt odumiranja tradicionalnih žanrova. Ako se ima u vidu činjenica da se od novinara sve do skora očekivalo da budu uporni tragači za otkrivanjem i tumačenjem suštine onoga što se oko nas dešava i o čemu oni izveštavaju, onda se, sasvim opravdano, postavlja pitanje mogu li se ti zadaci ispiniti kratkim, faktografskim žanrovskim formama. Ne govori li to o sve većoj površnosti savremenog novinarstva i o izmenjenoj ulozi novinara u novim medijima?

Celokupni posao u znatnoj meri otežava činjenica da je reč o prilično živoj materiji, da je izuzetno teško pratiti internet medije i da sa njihovih stranica neki tekstovi nestaju istom brzinom kojom na njih dolaze, a to znači za samo jedan tren.

\section{TRADICIONALNO ILI NOVO}

Prvi dnevni list na internetu, San Jose Mercury News, pojavio se 1993. godine, ali se za početak veb novinarstva najčešće uzima 1982. godina kada su se pojavili ekperimentalni video-tekst servisi, koji su štampane publikacije i druge interaktivne servise prikazivali preko TV ekrana [1]. Servis je bio strogo kontrolisan od strane velikih medijskih korporacija Times Mirror i Knight Rider, a svaki pokušaj publike da utiče na njegov sadržaj bio je onemogućen. Kao neuspešan ugašen je 1986. godine.

Međutim, kasnijih godina, u čitav posao uključile su se i neke druge američke kompanije poput CompuServe, Prodigy i AOL i to na taj način što su počele da koriste mreže za pružanje usluga poput četa i raznih foruma, iako one same nisu bile vezane za novinarstvo. „Njihov uspeh, kao i vrtoglavi napredak u kompjuterskim tehnologijama, razvoj World Wide Web-a krajem 80-ih i početkom 90-ih, HTML-a (1990-1992), grafički brauzer Mosaic (1993), razvoj elektronske pošte, naterao je medijske kompanije da ulože ogroman trud i pokrenu novi talas u onlajn novinarstvu i prvi talas veb novinarstva" [2].

Sve je funkcionisalo na ideji besplatnog korišćenja usluga, jer se računalo da će komercijalne efekte doneti reklame koje se budu objavljivale, a ne novinarski sadržaji. Veoma brzo, na hiljade korisnika lansiralo je svoje manje, inovativne, i specijalizovane sajtove, a nešto kasnije nastali su blogovi, kao novi model za lansiranje onlajn vesti. Gotovo preko noći razvijena su tri modela veb medija: direktan prenos postojećeg štampanog medija na veb platformu; prenos štampanog medija uz dodatak određenih originalnih sadržaja; potpuno nov, originalan sadržaj, uključujući video i audio.

Godine koje su usledile donele su punu ekspanziju veb novinarstva, ali i turbulencije u okviru kojih je bilo dosta ekonomskih promena. Pa ipak, „internet se nije dao, te se iz krize (početkom 2000. godine, prim. aut.) vratio jači nego ranije, u novom pakovanju i s novim karakteristikama koje će stvoriti ono što danas zovemo Web 2.0". ${ }^{1}$ Praktično, medijske kompanije odlučile su da u izradu sadržaja uključe korisnike, čime su oni postali partneri u istom poslu.

1 Termin Web 2.0 odnosi se na veb-sajtove koji dobijaju makar određenu vrednost od akcija korisnika: veb-izdavači stvaraju platforme umesto sadržaja, a korisnici stvaraju sadržaj. 
Dakle, u vreme video-teksta imali smo situaciju u kojoj su vlasnici sajtova sve kontrolisali, a krajnji korisnici nisu imali mogućnosti da utiču na kvalitet proizvoda koji im se nudi; kasnije, u prvoj fazi veb novinarstva, krajnji korisnici su se izborili za besplatan sadržaj i za kontrolu nad tim sadržajem, a u drugoj fazi je podeljena i kontrola, ali i sadržaj.

Vlasnici i korisnici sajtova shvatili su da su jedni drugima potrebni, da velike mreže bez publike ne predstavljaju nikakvu vrednost, da su krajnjim korisnicima potrebni sadržaji velikih novinskih kompanija da bi mogli da komentarišu i nadograđuju. Tako je lagano stvarana jedna nova generacija novinara.

Tradicionalni mediji, a među njima pre svih velike svetske novinske agencije, ne napuštajući standarde i praksu rada novinara napravile su veliki zaokret ka društvenim mrežama i takozvanom građanskom novinarstvu, jer se njihovo prisustvo praktično ne može ignorisati. Asošijetet pres, jedna od najvećih svetskih novinskih agencija, koja širom sveta zapošljava oko 3.000 novinara, osnovala je poseban Centar za društvene mreže, kao deo tzv. Nerve Centra. U svom sastavu ovaj centar ima i Centar za vesti, Centar za standarde i Centar za produkciju. Loren Mek Kalag (Lauren McCullough), koja se nalazi na dužnosti menadžerice društvenih mreža AP-a, tvrdi da su novinari ove agencije aktivni na društvenim mrežama i da oni imaju nekoliko adresa, kao što su @APStylebook na tviteru i kanal na You Tubeu koji pomažu da se i publika aktivno uključi u stvaranje i proizvodnju vesti [3]. Menadžerica AP naglašava da je potraga za vestima zahvaljujući društvenim mrežama olakšana, ali da pritom novinari moraju da zadrže standarde koje kao pripadnici profesije odavno imaju, i da svaku vest koji na taj način dobiju obavezno provere.

Zanimljivo je, međutim, da uprkos punoj ekspanziji interneta, građani širom sveta i dalje prednost daju televiziji nad internetom. Prema istraživanju koje je sproveo Rojtersov institut za proučavanje novinarstva, a o čemu inače informiše Evropska opservatorija za novinarstvo, tradicionalni večernji dnevnici i dalje su popularniji od internet stranica kada su u pitanju vesti iz sveta [4]. Njihovo istraživanje pokazalo je da u vreme kada se društvenim mrežama prečesto zamera zbog širenja dezinformacija o velikim međunarodnim događajima, pažljiv odabir televizijskih vesti podiže gledanost televizije. Autori istraživanja pod nazivom "Javni apetiti za vesti iz sveta na televiziji i internetu" navode da bitni svetski događaji mogu da povećaju prosečnu gledanost jedne informativne emisije za čak $20 \% .^{2}$

2 Istraživanje su tokom 2010. i 2011. godine uradili Ričard Sambruk, profesor žurnalistike na Univerzitetu u Kardifu, Dejvid Levi, direktor Rojtersovog instituta za proučavanje novinarstva i Sajmon Terington, bivši gostujući predavač na Rojtersovom institutu.
Ovo istraživanje zanimljivo je i zbog toga što je pokazalo da je dužina emitovanih priloga u TV emisijama bitno uticala na njihovu gledanost. Naime, dugi prilozi, oni koju su trajali duže od 15 do 20 minuta, nisu bili gledani, bez obzira na činjenicu da su jedan važan događaj oslikavali iz mnogo različitih uglova. Studija je, takođe, pokazala da se gledanost priloga na televiziji i internetu, bez obzira na njegov kvalitet i značaj, ne podudara. Oni koji koriste internet sami određuju koji će prilog gledati ili čitati, kao i koliko će mu vremena pokloniti, a to je obično kraće od vremena koje sličan prilog zasluži na televiziji.

\section{IZMENJENE ŽANROVSKE FORME}

Novinarske forme, za razliku od književnih, manje su složene i kratkovečnije. Internet je dramatično ubrzao protok informacija, pa neke od njih traju veoma kratko, ponekad ne duže od jedne sekunde. Pojave se i nestanu.

Teorija novinarskih žanrova posvećena je upravo normama, oblicima izražavanja shvaćenim kao obrascima koji se ponavljaju u medijima. U savremenom dobu klasičnu podelu novinarskih žanrova na faktografiju (podžanrovi - vest, izveštaj, klasični, tematski intervju pitanje - odgovor), beletristiku (reportaža, crtica, feljton, karikatura) i analitiku (članak, komentar, portret-profil ličnosti, kritika), zamenjuje, kako navodi teoretičar medija Neda Todorović, novijom podelom „na faktografiju (izveštačko novinarstvo) i interpretaciju (istraživačko novinarstvo)". Međutim, prema njenim rečima, i ova podela je, kao i prethodna, uslovna. „Hibridizacija, prožimanje oblika novinarskog izražavanja, odlika je gotovo svih aktuelnih praksi pisanja. I danas se pred našim očima određuju nove žanrovske granice, stvaraju se neke nove 'otvorene' forme, razvijaju se žanrovski sistemi i podsistemi” [5].

Istorijski prikaz razvoja hibridnosti žanrova, povezujući ga sa novim tehnološkim rešenjima, ponudio je novozelandski teoretičar Brenon Vud (Brennon Wood) i to na osnovu posmatranja, razvoja i menjanja različitih programskih vrsta na novozelandskoj televiziji od 1960ih do 1990-ih godina, koje su na kraju svojim mešanjem dovele do nastanka hibridnosti.

Različitim ukrštanjima činjenica, fikcije, zabave i oglašavanja i njihovim razvojem došlo je do stvaranja novih vrsta hibridnosti koje se mogu identifikovati, a svaka od njih stvara poseban doživljaj sveta, jer svaka od njih stvara drugačiji način ukrštanja između činjenica, fikcije, zabave i oglašavanja, a to su: re-enactment (drame i filmovi koji se temelje na ljudima i događajima koji postoje u spoljnom svetu, a konstruišu fikciju na temelju spoljnih činjenica), 
diversion (prikazuju ljude koji se predstavljaju kao oni sami), absorption (situacije se rekonstruišu: podudaraju se činjenice i finkcija), kao i infomercil (duže televizijske reklame od 30 minuta koje spajaju prikazivanje nekog proizvoda i svedočanstva ljudi ili stručnjaka o njegovoj funkcionalnosti: spajaju oglašavanje sa činjenicama) [6].

Vud smatra da je „razvoj hibridnosti krajem 1990ih godina postala rutina u celom svetu, kao i da su se mnogi teoretičari usmerili na proučavanje hibridnosti na osnovu najpoznatijih hibridnih formata - namešanja u dokumentarnom žanru i na pojavu „rijaliti televizije”. Po njegovom mišljenju „više pažnje bi trebalo usmeriti proučavanju tzv. informersijala, televizijskih reklama koje traju oko 30 -ak minuta, jer je to danas najrazvijeniji televizijski hibridni žanr, koji je zadnjih godina prekinuo dominaciju drugih".

Sasvim je izvesno da hibridnost nudi ogromne prostore za drugačije prihvatanje određenih informacija, posebno za učešće u njihovom komentarisanju i kanalisanju. Kako navodi Džej David Bolter (Jay David Bolter) u svom članku Težnja za transparentnošću u eri hibridizacije (The Desire for Transparency in an Era of Hibridity), hibridnost je prihvaćena strategija u produkciji i potrošnji popularnih medijskih formi i tehnologija. „Ono što novi mediji entuzijastično nazivaju konvergencija, nije samo mešavina različitih tehnologija u jedno jednostavno sredstvo, već pre svega proizvod različitih multifunkcionalnih uređaja, koji kao hibrid predstavljaju različita lica različitim korisnicima, koji se temelje na njihovim potrebama i povlasticama" [7].

Prema Žilu Brenstonu (Gill Branston) „različitost u mešanju 'repertoara elemenata' je sastavni deo mešanja žanra ili hibridnosti". To je posebno uobičajeno u novinarstvu i oglašavanju i predstavlja „deo procesa intertekstualnosti”. Brenston pojam intertekstualnosti objašnjava kao „pojam koji se odnosi na tekst, koji se poziva na neki prethodni tekst ili na neko prethodno znanje, a ono nas zajedno sa hibridnošću podseća kako narativne forme u televiziji i filmu kombinuju žanrove" [8]. Sve ovo neodoljivo podseća na sve češću praksu linkovanja koju imamo kod tekstova koji se objavljuju na internet portalima.

\section{4. ŽANROVI NADOMAĆOJ MEDIJSKOJ SCENI}

Savremeno novinarstvo, pod uticajem tehnologije, sve više liči na dijalog, a ne na monolog. Mnogo starih praksi je napušteno, a u svakodnevnu novinarsku terminologiju uključuju se novi pojmovi poput bloga, građanskog novinarstva i sl. Neda Todorović ističe da „u eri preobilja informacija, kada novinari nisu više jedini posrednici između događaja i konzumenata, dezorijentisani građani i dalje, s pravom zahtevaju eksplikaciju onog što se u svetu u kome žive dešava, ali da pored tumačenja (zašto?) traže i predviđanje (šta dalje?)". Stoga je, po njenim rečima, logično da u „osnove znanja modernog novinara 21. veka spada, pored tzv. novinarskog načina mišljenja i poznavanje, vladanje novinarskim žanrovima i podžanrovima izražavanja”.

„Odgovorno novinarstvo savremene, elektronske, ere podrazumeva standarde pouzdanosti i profesionalnosti koji počivaju na novinarskom znanju, etičnosti i vrhunskom zanatu. Ti standardi efikasnosti, etičnosti i efektnosti, ne odnose se samo na vladanje najnovijim tehnologijama, kako se površno zaključuje, oni se zasnivaju na nepromenljivim pravilima i vrednostima novinarske profesije kao zanimanju sa punim radnim vremenom" [9].

Mešanje žanrova je sve češće. Nekada je žanrovska čistoća predstavljala ogledalo kvaliteta medija, ali je današnja hibridizacija trend koji se sve više podstiče. Novi mediji proizvide forme izražavanja, pisanja tekstova koji su zbog svoje multimedijalnosti sve popularnije kod mladih ljudi. „Te nove forme izražavanja u onlajn novinarstvu uslovljene medijskim potencijalima i naprednim tehnološkim mogućnostima počivaju u osnovi na elementarnim pravilima pisanja onih klasičnih. Model pisanja vesti principom obrnute piramide idealan je, neprevaziđen i dobrodošao u onlajn praksi pisanja" [10]. Zbog toga se mora shvatiti da uprkos promeni žanrovskih formi, novinarstvo ostaje novinarstvo samo ukoliko je istinito, zasnovano na punom uvažavanju usvojenih standarda i etičkih principa žuranlizma.

U mnogim aspektima, tradicionalna teorija žanrova primenjiva je i u okruženju interneta. Njihova funkcija i forma je i na internetu često takva da se mogu jasno raspoznavati vrste žarova. „Ono što doprinosi pojavi hibridnih žanrova jeste, pre svega, digitalnost i pristupačnost interneta, kao i mogućnost linkovanja i prisustvo hiperlinkova" [11]. Hibridni žanrovi su specifični u odnosu na tradicionalne novinarske žanrove i po posebnom grafičkom dizajniranju teksta za portal, po određivanju ključnih reči po kojima se može vršiti pretraga itd. To je način da se privuče pažnja posetilaca sajta, u moru naslova vesti koje kruže internetom. „Karakteristika hibridnih internetskih žanrova je i korišćenje multimedijalnih sadržaja: fotografija, audio zapisa, video zapisa, grafikona i drugih vrsta ilustracija. Cilj je uvek isti: da se kreira multimedijalni sadržaj" [12].

Većina domaćih tradicionalnih medija, kako štampanih, tako i elektronskih, poslednjih godina pokrenula je, 
uz primenu brojnih hibridnih žanrovskih formi, svoje veb portale, odnosno internet izdanja. Za kratko vreme oni su postali veoma popularni. Poslednji podaci govore da je sajt dnevnog lista Blic daleko najpopularniji, odnosno najposećeniji.

\section{| Broj jedinstvenih korisnika}

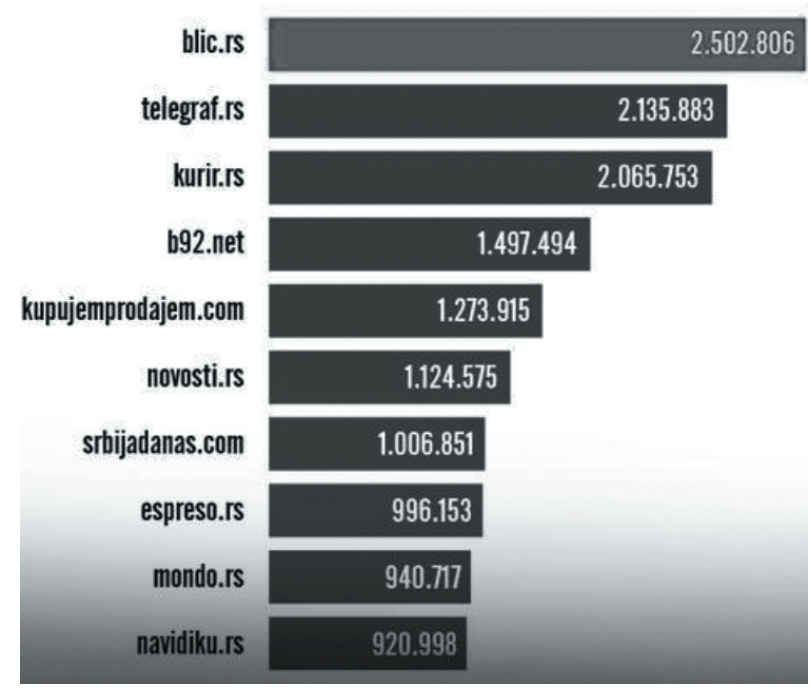

Izvor: Blic, 02.03.2017.

Prema podacima Gemiusa, sistema za praćenje posećenosti sajtova, portal Blic.rs je u januaru 2017. godine imao više od 2,5 miliona korisnika iz Srbije, tačnije 2.502.806, što apsolutno govori o uticaju koji ovaj portal ima na srpsku javnost. Ovome se mora dodati i veliki, ali neutvrđeni, broj onih koji su Blicov sajt posetili preko aplikacija za android i ajfon uređaje, što je novi dokaz uticajnosti internet izdanja ovih novina. Posećenost portalu Blic, pre svega, duguje kratkim žanrovskim formama, brzini prenošenja vesti i informacija, kao i interaktivnosti koja se nudi posetiocima.

\section{INTERESANTNOST VESTI}

Pod uticajem novih tehnologija promenili su se mediji, promenili su se žanrovi, promenio se način pisanja, promenila se publika, promenili su se novinari. Bez obzira na žanrovsku hibridizaciju, vesti su preživele i dalje su, možda više nego ikad, tražene na medijskom tržištu. Ali kakve?

Pojava Fejsbuka i Tvitera promenila je mnoge tradicionalne kriterijume po kojima se određivalo šta je to vest. Na snazi su drugačija pravila koja je, između ostalog, u svom blogu pod naslovom „Budućnost novina i veb portala i šta su danas vesti” opisao Istok Pavlović, profesor na Fakultetu za medije i komunikacije, koji je 2011. godine izabran za najboljeg blogera u Srbiji. Pavlović objašnjava da je „suština novina u tome da zadovolje ljudsku potrebu da saznaju šta ima novo, da dobiju svakog dana iznova osećaj da se nešto dešava, da su drugi ljudi u tom društvu živi i da nešto rade. Bilo da su to vesti iz sporta, politike, kulture" [13]. Međutim, gledajući svet oko sebe, Pavlović naglašava:

„da sve ukazuje na jednu veliku i nepobitnu činjenicu koja sve više postaje nepovratna realnost: $\mathrm{Fe}$ jsbuk su danas novine, a vesti su danas News feed na Fejsbuku. Verovatno većina ljudi koje poznajemo ujutro prvo ode na Fejsbuk da saznaju šta ko radi od prijatelja iz njihovog okruženja, a ne šta rade Tomislav Nikolić ili Angela Merkel. Ako ogromna većina ljudi ujutru detaljno iščitava ceo Fejsbuk, sve informacije o svojim prijateljima, a tek sporadično ode na sajt nekih novina ako se desi nešto baš epohalno, pa svi to šeruju, onda se postavlja logično pitanje - šta su u današnje vreme vesti dana za većinu ljudi?”

Postaje sasvim očigledno da je blizina vesti jedan od najznačajnijih kriterijuma za njihov odabir. Još ako je ona kombinovana sa tehnološkim mogućnostima koje mediji nude, ako je prikazana u hibridnoj formi, onda je interes ljudi uglavnom zadovoljen. Ljude danas, tvrdi Pavlović, ne interesuje u istoj meri kao ranije šta rade nedodirljivi ljudi na vlasti, što im je prikazivano duže od 400 godina, koliko otprilike traje moderna istorija novinarstva, već pre svega ono što se dešava u njihovom okruženju, ono što se dešava njihovom komšiji, drugarici, prijatelju, sestri... Možda ih ni ranije nije previše interesovalo šta rade kraljevi, političari, ministri i njima slični, ali su bili prinuđeni da čitaju o tome, jer im je medijska industrija servirala upravo takve, žanrovski strogo ukalupljene priče. Pavlović ističe da Fejsbuk nema urednika koji će nasilno svakom korisniku da stavi prvu vest u News feedu: „Mlađan Dinkić otvorio fabriku”. „Umesto toga, algoritam sklapa posebnu 'naslovnu stranu' za svakog čitaoca. U vrh će izaći statusi i linkovi ljudi sa kojima imamo najveću interakciju i stvari koje su postavili ljudi iz našeg bliskog okruženja" [14].

Paralelno sa izborom vesti mora se razmišljati o izgledu teksta koji se nudi, jer se pisanje za štampane i onlajn medije razlikuje. Neki od osnovnih postulata, poput obrnute piramide, kratkih pasusa i naslovne kompozicije su opstali, ali je uključivanje video i audio sadržaja doprinelo primamljivosti tekstova na vebu. Međutim, i dalje je veoma teško pretraživati ove sadržaje, pa je zbog toga tekst i dalje primaran kada se želi pronaći određeni sadržaj. 


\section{ZAKLJUČAK}

Internet i vreme promenili su staru paradigmu o podeli novinarskih žanrova na faktografske, analitičke i beletrističke. Danas je mnogo ispravnije govoriti o hibridizaciji žanrova.

Uprkos činjenici da su te nove žanrovske forme obogaćene rešenjima koja je omogućila tehnologija, poput fotografije, tonskih, audio i video zapisa, grafika i animacije, ostaje činjenica da suštinu novinarskog proizvoda i dalje čini tekst. Možda će se kroz vreme i ova karakteristika menjati, ali se niko od teoretičara medija na usuđuje da o ovome govori sa većom dozom izvesnosti. Zbog toga je novinarskim praktičarima potrebno dobro poznavanje osnovnih kategorija iz Teorije novinarskih žanrova, ali i sve bolje poznavanje mogućnosti koje internet pruža.

Sasvim je izvesno da je obrnuta piramida kao stil pisanja novinarskih tekstova preživela, ali da se ukupan medijski proizvod neprekidno menja. Današnji novinarski tekstovi su kraći, sa krupnijim, rekli bismo i provokativnijim naslovima, obavezno opremljeni fotografijom, grafikama i sličnim proizvodima koje tehnologija omogućava. Taj trend se mora nastaviti, jer sve mlađa publika, koja se uglavnom informiše preko mobilnih telefona i Fejsbuka, ima nove poglede na informisanje u celini. Ona ne želi da čita „vesti od juče”.

Digitalno doba donelo je promenu posle koje su novinari u novim medijima postali glavni razlog verovanja ili korišćenja određenih onlajn izvora vesti. Reputacija novih novinara je jedan od ključnih razloga zbog kojih neko čita određene vesti na internetu. Rastuća važnost individualnih karakteristika novinara podstaknuta je lakoćom distribuiranja novinskih sadržaja. Međutim, bez obzira na činjenicu da li se piše za stare ili nove medije, ostaje nepromenjiva potreba da se bude medijski pismen, kako bi se ispunila jedna od osnovnih etičkih premisa žurnalističke profesija, a ona se pre svega odnosi na istinitost i etičnost.

\section{LITERATURA}

[1] Mitić, Aleksandar. 2010. Istorijat veb novinarstva i uloga novinara na internetu, u: Priručnik veb novinarstva, ur. A. Mitić, Beograd: Udruženje novinara Srbije, str. 9.

[2] Isto, str. 12.

[3] McCullough, Lauren. 2010. Social Media Has 'Central Role in Our Newsgathering,' Says AP's, vidljivo na sajtu www.poynter.org/2010/social-media-hascentral-role-in-our-newsgathering-says-aps-laurenmccullough/100101/, posećeno 12.2.2016.

[4] http://rs.ejo-online.eu/novi-mediji-i-web-2-0/vestiiz-sveta-se-i-dalje-prate-na-televiziji-a-ne-na-internetu, posećeno 12.2.2016.

[5] Todorović, Neda. 2013. Prilog teoriji žanrova u postnovinarstvu, u: Medijski dijalozi, god, VI, br. 17, ur. M. Drašković, Podgorica: Istraživački medijski centar, str. 29.

[6] Wood, Brennon. 2004. A World in Retreat: The Reconfiguration of Hybridity in 20th-Century, New Zealand Television, u Media Culture Society 26 (1), Sage Publications, str. 48-50.

[7] Bolter, J. David. 2006. The Desire for Transparency in an Era of Hybridity. Leonardo 39, no. 2, str. 109.

[8] Branston, Gill. 2006. Understanding Genre, u: Gillespie, Marie, Analyising Media Texst, New York: Open University Press.

[9] Todorović, Neda. 2013. Prilog teoriji žanrova u postnovinarstvu, u: Medijski dijalozi, god, VI, br. 17, ur. M. Drašković, Podgorica: Istraživački medijski centar, str. 14.

[10] Isto, str. 30.

[11] Gruhonjić, Dinko. 2015. Odnos novinarskih žanrova na tradicionalnom radiju i radiju na internetu, doktorska disertacija, Beograd: Fakultet političkih nauka, str. 258.

[12] Isto, str. 258.

[13] www.istokpavlovic.com/blog/buducnost-novinai-web-portala-i-sta-su-danas-vesti/,posećeno 18.11.2015

[14] Isto 


\title{
INTERNET AS MAIN AGENT OF TRANSFORMATION OF MEDIA CONTENT GENRES SUMMARY
}

\begin{abstract}
:
Today's contemporary world is enriched with new techologies which have been rapidly changing usual mass media contents. In the past, information travelled for days, even months, from one side of the world to another. Today, however, it seems to travel at the speed of light. These kinds of changes also condition changes in media genres structures, which are today mostly predominated by the news and information. All other analytical texts, comments, reviews and even coverage stories are in the second place. Some new forms, such as increasingly popular blogs, appeared at the same time.

This written work will try to find an answer to the question, while bringing changes into genres' forms, what is the amount of impact that time has had on the truthfulness of media contents we are exposed to every day. Also, it will point out the need for media literacy of all immediate media participants, such as owners, editors, journalists, media users.
\end{abstract}

\section{Keywords:}

media, genres, media literacy, the internet, blog. 